\title{
Considerations on goat milk biochemical composition
}

\author{
Andreea ANGHEL, ${ }^{1,2}$ Daniela JITARIU* ${ }^{1}$ Dorina NADOLU, ${ }^{2,3}$ Zoia ZAMFIR, ${ }^{2}$ and Elena ILIŞIU ${ }^{2}$ \\ I" Ovidius" University of Constanta, Romania, Faculty of Natural and Agricultural Sciences \\ ${ }^{2}$ Research and Development Institute for Sheep and Goat Breeding Palas \\ ${ }^{3}$ Romanian National Association of Goat Breeders - ANCC Caprirom
}

\begin{abstract}
The benefits of human consumption of goat's milk are given by the presence in this milk of short-chain fatty acids (approximately $20 \%$ are short-chain fatty acids) and medium-chain fatty acids (55\%), this milk being easier to digest. An important qualitative indicator of goat's milk with technological, nutritional and dietary impact is the fat content. Our data show that the percentage of milk fat increases immediately after parturition, then decreases for most of the lactation. This is due to two factors: a diluting effect, by increasing the volume of milk to the maximum level of lactation and a decreasing effect of lipid mobilization, which leads to a decrease in the plasma level of unesterified fatty acids (especially $\mathrm{C} 18: 0$ and $\mathrm{C} 18: 1$ ), with a role in lipid synthesis in the mammary gland. From the third month of lactation, the average daily amount of milking milk undergoes only slight variations. Also, the fat and protein percentage remain relatively constant during June-August. In summer there was an increase in the levels of monounsaturated, polyunsaturated fatty acids and of conjugated linoleic acids in milk, compared to spring. Our results indicate that multiparous Carpathian breed females, whose food comes mostly from grazing, produce milk during the summer with a ratio between omega- 6 and omega- 3 below 4 .
\end{abstract}

Keywords: goat milk; fatty acids; omega 6/omega 3 ratio; conjugated linoleic acid

\section{Introduction}

Goat's milk is a very well tolerated by people allergic to cow's milk, thus representing an alternative to consumption. In addition to their contribution in attributing the specific smell of goat to dairy products, short chain fatty acids and medium chain fatty acids in high proportion have either other properties, as: antibacterial, antiviral, inhibit the development of cholesterol deposits and have a rapid absorption in the intestine [1].

By modulating food rations, it is also possible to increase in milk the content of polyunsaturated fatty acids, thus improving its nutritional value. Polyunsaturated fatty acids are associated with a reduced risk of cardiovascular diseases [2]. Many researches have focused on the antioxidant and anticarcinogenic characteristics of conjugated linoleic acid (CLA), coming from ruminal biohydrogenation of linoleic acid and of linolenic acid. It has been shown that the presence of these acids in drinking milk can decrease oxidative stress and atherosclerosis and can improve the profile of blood lipid, while reducing the risk of developing skin and mammary gland tumors in humans [3].

There is evidence that certain forage species, especially leguminous, can significantly influence the composition of bioactive fatty acids and lipids in the milk of ruminants. Thus, the additional health benefits of lipids from goat's milk can be attributed to the specific feeding behavior of goats, namely a selective one, but also to the interaction between the components of the ratio and the specific digestion of goats $[4,5]$. A study conducted in France showed that rations in which grazing has a high share, compared to hay-based rations, were associated with increased levels of xanthophyll, retinol and $\alpha$-tocopherol in Rocamadour cheese and a high percentage of concentrates in the ratio resulted in a lower content of xanthophyll and of $\alpha$-tocopherol [6].

The aim of our experiments was to test the effect of nutrition on the quantity and quality of milk in multiparous goats, grown in the same conditions (semiintensive system), of different breeds: local Carpathian, crossbreed goats R1 Saanen $\times$ Carpathian and crossbreed goats R1 French Alpine $\times$ Carpathian, from a farm in Constanţa county, Romania.

\section{Experimental}

\subsection{Animal feeding}

Starting with April, the animals grazed and received as food supplement alfalfa hay and corn and barley middling. They had free access on a permanent pasture with the following floristic structure: $30 \%$ legumes and $70 \%$ grasses.

\subsection{The method of collecting milk samples}

Milk samples were collected individually from all the animals included in the experiment, monthly, twice a day for a period of 5 months. For this purpose, the milk that was milked in the morning and in the evening were weighed individually. Individual milk samples were also taken for performing the qualitative analysis.

\subsection{Materials and reagents}

Methanol (99.9\%), chloroform (99.9\%), hexane, sulfuric acid $(99.9 \%)$, sodium hydroxide, petroleum 
ether for analysis were purchased from Fisher Scientific UK. The forage (alfalfa hay, barley, maize) was purchased from the local market.

\subsection{Methods}

Fats, proteins and lactose from milk were analyzed by electrochemical method in a standardized Funke Gerber Lactostar analyzer for goat's milk.

In parallel, the profile of milk fatty acids (FA) was determined in the form of methyl esters of fatty acids (FAME) by gas chromatographic method by using a Perkin Elmer-Clarus 500 Chromatograph with capillary column and high polarity stationary phase $(0.25 \mathrm{~mm}$ inner diameter and $0.25 \mu \mathrm{m}$ thick film). Analyzes were carried out The National Research - Development Institute for Animal Biology and Nutrition (INCDBNAIBNA Balotești) [7, 8].

\section{Results and discussion}

The results on the quantity and quality of milk at Carpathian breed females are presented in Table 1.

Table 1. Milk quantity (g) and composition (\%) variation in Carpathian breed females (mean \pm standard deviation)

\begin{tabular}{|l|c|c|c|c|}
\hline $\begin{array}{l}\text { Lactation } \\
\text { period }\end{array}$ & $\begin{array}{c}\text { Quantity } \\
(\mathbf{g})\end{array}$ & $\begin{array}{c}\text { Fat } \\
(\boldsymbol{\%})\end{array}$ & $\begin{array}{c}\text { Protein } \\
(\boldsymbol{\%})\end{array}$ & $\begin{array}{c}\text { Lactose } \\
(\boldsymbol{\%})\end{array}$ \\
\hline \multirow{2}{*}{ Month 1 } & $1439.65 \pm$ & $3.71 \pm$ & $3.17 \pm$ & $4.59 \pm$ \\
& 38.00 & 0.0224 & 0.0102 & 0.0178 \\
\hline \multirow{2}{*}{ Month 2 } & $1636.85 \pm$ & $3.61 \pm$ & $3.11 \pm$ & $4.58 \pm$ \\
& 53.44 & 0.0221 & 0.0091 & 0.0171 \\
\hline \multirow{2}{*}{ Month 3 } & $1607.50 \pm$ & $3.63 \pm$ & $3.15 \pm$ & $4.62 \pm$ \\
& 30.84 & 0.0216 & 0.0085 & 0.0162 \\
\hline \multirow{2}{*}{ Month 4 } & $1566.45 \pm$ & $3.66 \pm$ & $3.14 \pm$ & $4.60 \pm$ \\
& 48.52 & 0.0220 & 0.0086 & 0.0156 \\
\hline \multirow{2}{*}{ Month 5 } & $1543.60 \pm$ & $3.67 \pm 0$. & $3.16 \pm$ & $4.59 \pm$ \\
& 48.32 & 0229 & 0.0094 & 0.0172 \\
\hline
\end{tabular}

According to Table 1, the corn middlings and barley middlings supplements increase the amount of energy ingested. There is a significant increase in the amount of milk milked in the second month of lactation compared to the first month of lactation, from the daily value of 1.4 $\mathrm{kg}$ milk to $1.6 \mathrm{~kg}$ milk, an increase associated with the decrease of fat and protein percentages. The fat content of milk increases rapidly after parturition, then has showed a decrease for most of the lactation.

This phenomenon is due to an increase of milk volume until the peak of lactation and a reducing of a lipid mobilization that leads to a decrease of nonesterified fatty acids in the plasma level, involved in lipid synthesis in the mammary gland [9]. From the third month of lactation, the daily average amount of milk undergoes only slight variations. In addition, the percentage of protein and fat remains constant during the period June-August.

Lactose, the principal carbohydrate in milk is synthesis from glucose in the mammary gland. It promotes absorption of calcium, phosphorus, and magnesium at intestinal level and the use of vitamin D, also. It maintains the osmotic balance blood flow alveolar cells in the mammary gland. Smaller quantities of lactose are found in colostrum at the beginning and at the end of lactation [10], as in our studies, in all females groups. For French Alpine $\times$ Carpathian crossbreed females (Table 2) and the Saanen $\times$ Carpathian crossbreeds (Table 3) there is an increase of milk quantity starting with the second month of lactation, when the largest amount of milk is made.

Table 2. Milk quantity (g) and composition (\%) variation in French Alpine $\times$ Carpathian crossbreed females (mean \pm standard deviation)

\begin{tabular}{|l|c|c|c|c|}
\hline $\begin{array}{l}\text { Lactation } \\
\text { period }\end{array}$ & $\begin{array}{c}\text { Quantity } \\
(\mathbf{g})\end{array}$ & $\begin{array}{c}\text { Fat } \\
(\boldsymbol{\%})\end{array}$ & $\begin{array}{c}\text { Protein } \\
(\boldsymbol{\%})\end{array}$ & $\begin{array}{c}\text { Lactose } \\
(\boldsymbol{\%})\end{array}$ \\
\hline \multirow{2}{*}{ Month 1 } & $2341.30 \pm$ & $3.43 \pm$ & $2.92 \pm$ & $4.61 \pm$ \\
& 36.70 & 0.0224 & 0.0078 & 0.0096 \\
\hline \multirow{2}{*}{ Month 2 } & $2571.80 \pm$ & $2.78 \pm$ & $3.12 \pm$ & $4.59 \pm$ \\
& 70.00 & 0.0217 & 0.0057 & 0.0098 \\
\hline \multirow{2}{*}{ Month 3 } & $2514.95 \pm$ & $3.93 \pm$ & $3.69 \pm$ & $4.62 \pm$ \\
& 58.04 & 0.0220 & 0.0065 & 0.0097 \\
\hline \multirow{2}{*}{ Month 4 } & $2467.85 \pm$ & $4.58 \pm$ & $3.71 \pm$ & $4.63 \pm$ \\
& 60.87 & 0.0225 & 0.0063 & 0.0097 \\
\hline \multirow{2}{*}{ Month 5 } & $2405.85 \pm$ & $4.40 \pm$ & $3.72 \pm$ & $4.61 \pm$ \\
& 39.34 & 0.0222 & 0.0082 & 0.0091 \\
\hline
\end{tabular}

Table 3. Milk quantity (g) and composition (\%) variation in Saanen $\times$ Carpathian crossbreed females (mean \pm standard deviation)

\begin{tabular}{|l|c|c|c|c|}
\hline $\begin{array}{l}\text { Lactation } \\
\text { period }\end{array}$ & $\begin{array}{c}\text { Quantity } \\
(\mathbf{g})\end{array}$ & $\begin{array}{c}\text { Fat } \\
(\boldsymbol{\%})\end{array}$ & $\begin{array}{c}\text { Protein } \\
(\boldsymbol{\%})\end{array}$ & $\begin{array}{c}\text { Lactose } \\
(\boldsymbol{\%})\end{array}$ \\
\hline \multirow{2}{*}{ Month 1 } & $2400.75 \pm$ & $4.00 \pm$ & $3.81 \pm$ & $4.62 \pm$ \\
& 75.40 & 0.0283 & 0.0086 & 0.0116 \\
\hline \multirow{2}{*}{ Month 2 } & $2603.45 \pm$ & $3.17 \pm$ & $3.08 \pm$ & $4.65 \pm$ \\
& 84.46 & 0.0268 & 0.0082 & 0.0108 \\
\hline \multirow{2}{*}{ Month 3 } & $2543.65 \pm$ & $3.81 \pm$ & $3.21 \pm$ & $4.64 \pm$ \\
& 40.65 & 0.0273 & 0.0073 & 0.0104 \\
\hline \multirow{2}{*}{ Month 4 } & $2487.25 \pm$ & $3.82 \pm$ & $3.61 \pm$ & $4.65 \pm$ \\
& 63.72 & 0.0272 & 0.0064 & 0.0114 \\
\hline \multirow{2}{*}{ Month 5 } & $2417.15 \pm$ & $3.83 \pm$ & $3.64 \pm$ & $4.63 \pm$ \\
& 56.65 & 0.0275 & 0.0087 & 0.0123 \\
\hline
\end{tabular}

The percentage of milk fat is significantly higher in both categories of crossbreeds compared to the Carpathian breed, although during the lactation months it suffers the same variation: a decrease in the second month, due to quantitative increase, followed by an increase during the summer months.

Generally, milk from animals farmed on pastures with optimum nutritional quality have a high fat content, due to high-fiber feed [9]. Moreover, studies have shown that goats' milk is rich in micro components (fatty acids and vitamins), volatile compounds, phenolic compounds, favorable to human nutrition and health. The grazing positively influences the fat in milk, an aspect highlighted by other researchers as well. Soryal et al. [11] recorded a higher percentage of milk fat at grazed Alpine breed, compared to those maintained in the shelter and fed with alfalfa hay. Some dietary fatty acids are involved as factors influencing human health $[12,13]$. Dietary sources from ruminants (milk, cheese and meat) contain more conjugated linoleic acid (CLA) than foods obtained of non-ruminant origin. Ruminant dairy products are the major dietary source of CLA, principally represented by the cis- 9 , trans- 11 isomer (rumenic acid), but also by the trans-10, cis-12 isomer [14]. The profile of fatty acids and the content of conjugated linoleic acids are different depending on the calendar month, similar results being obtained in other experiments of this kind, performed on animals in which grazing is the main feeding system [15]. Tsiplakou et al. showed that CLA content of grazing goat milk fat increased significantly in April - May (early growth 
stage of grass) and then declined, while that of indoors husbandry was constant during the same period [16].

Table 4. The profile of fatty acid and conjugated linoleic acid (CLA) content in milk, at Carpathine breed females (mean \pm standard deviation)

\begin{tabular}{|l|c|c|c|c|c|}
\hline $\begin{array}{c}\text { Characteristics } \\
\text { (g/100 g fatty } \\
\text { acids) }\end{array}$ & April & May & June & July & August \\
\hline Saturated fatty & $70.36 \pm$ & $71.23 \pm$ & $68.43 \pm$ & $67.33 \pm$ & $67.46 \pm$ \\
acids & 1.4141 & 0.7071 & 2.1211 & 2.5351 & 3.8284 \\
\hline Monounsaturated & $23.36 \pm$ & $22.32 \pm$ & $24.16 \pm$ & $25.00 \pm$ & $25.88 \pm$ \\
fatty acids & 1.2613 & 1.0113 & 0.9447 & 1.2023 & 1.1533 \\
\hline Polyunsaturated & $4.51 \pm$ & $4.77 \pm$ & $6.03 \pm$ & $6.16 \pm$ & $5.06 \pm$ \\
fatty acids & 1.0233 & 0.5687 & 0.2523 & 0.6523 & 0.7264 \\
\hline$\Omega 6 / \Omega 3$ Ratio & $9.51 \pm$ & $5.91 \pm$ & $2.84 \pm$ & $3.09 \pm$ & $3.91 \pm$ \\
& 0.3413 & 0.6674 & 0.2214 & 0.1115 & 0.6743 \\
\hline CLA & $0.40 \pm$ & $0.38 \pm$ & $0.85 \pm$ & $0.77 \pm$ & $0.54 \pm$ \\
& 0.0284 & 0.02632 & 0.0365 & 0.0321 & 0.0544 \\
\hline
\end{tabular}

Table 5. Fatty acid profile and conjugated linoleic acid (CLA) content in milk, at French Alpine $\times$ Carpathian crossbreed females (mean \pm standard deviation)

\begin{tabular}{|l|l|l|l|l|l|}
\hline $\begin{array}{c}\text { Charac- } \\
\text { teristics } \\
\text { (g/100 g } \\
\text { fatty } \\
\text { acids) }\end{array}$ & April & May & June & July & August \\
\hline $\begin{array}{l}\text { Saturated } \\
\text { fatty } \\
\text { acids }\end{array}$ & $73.35 \pm$ & $71.93 \pm$ & $66.94 \pm$ & $66.43 \pm$ & $67.49 \pm$ \\
\hline $\begin{array}{l}\text { Monouns } \\
\text { aturated } \\
\text { fatty } \\
\text { acids }\end{array}$ & $20.48 \pm$ & $21.96 \pm$ & $25.26 \pm$ & $25.35 \pm$ & $25.87 \pm$ \\
\hline $\begin{array}{l}\text { Polyunsat } \\
\text { urated }\end{array}$ & 4.0935 & 1.8734 & 1.8562 & 2.1342 & 2.3851 \\
fatty \\
acids
\end{tabular}

Table 6. Fatty acid profile and conjugated linoleic acid (CLA) content) in milk, at Saanen $\times$ Carpathian crossbreed females during the experiment (mean \pm standard deviation)

\begin{tabular}{|l|l|l|l|l|l|}
\hline $\begin{array}{c}\text { Characteristics } \\
\text { (g/100 g fatty } \\
\text { acids) }\end{array}$ & April & May & June & July & August \\
\hline Saturated fatty & $71.60 \pm$ & $70.65 \pm$ & $61.46 \pm$ & $66.81 \pm$ & $67.77 \pm$ \\
acids & 2.0149 & 1.8743 & 1.9823 & 1.7843 & 2.0199 \\
\hline Monounsaturated & $22.02 \pm$ & $23.87 \pm$ & $30.42 \pm$ & $25.09 \pm$ & $25.83 \pm$ \\
fatty acids & 1.0621 & 1.2021 & 0.8780 & 1.1793 & 1.1141 \\
\hline Polyunsaturated & $5.13 \pm$ & $3.92 \pm$ & $6.56 \pm$ & $6.44 \pm$ & $4.94 \pm$ \\
fatty acids & 1.1011 & 0.6811 & 0.3524 & 0.298 & 1.0112 \\
\hline$\Omega 6 / \Omega 3$ Ratio & $8.32 \pm$ & $6.16 \pm$ & $5.46 \pm$ & $3.62 \pm$ & $4.16 \pm$ \\
& 0.3524 & 0.2132 & 0.2019 & 0.5273 & 0.4253 \\
\hline CLA & $0.63 \pm$ & $0.35 \pm$ & $0.71 \pm$ & $0.80 \pm$ & $0.52 \pm$ \\
& 0.0213 & 0.0119 & 0.0098 & 0.0283 & 0.0413 \\
\hline
\end{tabular}

The monounsaturated, polyunsaturated fatty acids and conjugated linoleic acids levels in milk increased in summer months compared to the levels registered in spring months, and the saturated fatty acids level decreased during the summer months. Results that are considered similar were obtained in other experiments performed on grazing animals [17].

A diet rich in omega 6 acids results in an increased ratio of omega-6/omega-3. This increased ratio is associated with chronic low-grade inflammation, which favors Alzheimer's, heart disease, cancer, obesity [18]. By reducing this ratio, the inflammatory reaction of the body decreases and the risk of chronic diseases is reduced. The recommended optimum ratio is less than 5 , but in animal products this ratio is different, between 10 and $15[19,20]$. Our data indicate that Carpathian females, whose food comes mostly from grazing, produce milk with a ratio below 4 during the summer. Results that are considered similar have been obtained on primiparous goats grown under similar conditions [21].

\section{Conclusions}

Our results confirm that by modulating the ration we can improve animal productivity, within the limits of genetic potential. Also, the biochemical analyzes carried out to assess the quality of the milk are in line with those of numerous other studies, which have shown that the milk from goats fed on pasture is richer in fat-soluble vitamins, in unsaturated fatty acids and in conjugated linoleic acid, besides the high content of fatty acids with medium chain. Moreover, goats farmed on pastures have a medium chain fatty acid profile that is improved, compared to those fed conventionally with concentrated feed.

\section{Conflict of interest}

No conflict of interest declared.

\section{References}

[1]. Y. Chilliard, A. Ferlay, Dietary lipids and forage interaction on cow and goat milk fatty acid composition and sensory properties, Reproduction Nutrition Development 44 (2004) 467-492. DOI: 10.1051/rnd:2004052

[2]. C.M. Albert, C.H. Hennekens, C.J. O Donnell, U.A. Ajain, V.J. Carey, W.C Willet, Fish consumption and risk of sudden cardiac death, Journal of the American Medical Association 279 (1998) 23-28

[3]. K.J. Shingfield, S. Ahvenjärvi, V. Toivonen, A. Vanhatalo, P. Huhtanen, J.M. Griinari, Effect of incremental levels of sunflower-seed oil in the diet on ruminal lipid metabolism in lactating cows, British Journal of Nutrition 99 (2008) 971-983

[4]. A. Lucas, E. Rock, C. Agabriel, Y. Chilliard, J.B. Coulon, Relationships between animal species (cow versus goat) and some nutritional constituents in raw milk farmhouse cheese, Small Ruminant Research 75 (2008) 243-248.

[5]. M.R. Sanz Sampelayo, Y. Chilliard, P. Schmidely, J. Boza, Influence of type of diet on the fat constituents of goat and sheep milk, Small Ruminant Research 68 (2007) 42-63.

[6]. Y. Chilliard, A. Ferlay, J. Rouel, G. Lamberet, A review of nutritional and physiological factprs affecting goat milk lipid synthesis and lipolysis, Journal of Dairy Science 86 (2003) 1751-1770.

[7]. S. Toma, C. Dragomir, M. Habeanu, M. Ropota, A. Cismileanu, H. Grosu, Effects of partial or total replacement of sunflower meal with camelina meal on dairy cows' milk fatty acids profile, Archiva Zootechnica 18 (2015) 85-94. 
[8]. I. Voicu, I. Surdu, A. Cismileanu, A. Sava, A. Anghel, S. Zamfirescu, Strategii optimizate de hrănire a caprinelor in conditiile valorificării resurselor furajere specific Romaniei, Marlink Publishing House, pp. 30-39 (2017).

[9]. Y. W. Park, M. Juarez, M. Ramos, G.F. Haenlein, Physico-chemical characteristics of goat and sheep milk, Small Ruminant Research 68 (2007) 88-213.

[10]. P. Morand-Fehr, V. Fedele, M. Decandia, Y. Frileux, Influence of farming and feeding system on composition and quality of goat and sheep milk, Small Ruminant Research 68 (2007) 20-34.

[11]. K.A. Soryal, S.S. Zeng, B.R. Min, S.P. Ha, Effect of feeding treatments and lactation stages on composition and organoleptic quality of goat milk Domiati cheese, Small Ruminant Research 52 (2004) 109-116.

[12]. A.C. Ribeiro, S.D. Ribeiro, Specialty products made from goat milk, Small Ruminant Research 89 (2010) 225-233. DOI: 10.1016/S09214488(03)00249-9

[13]. R.J. Nicolasi, E.J. Rogers, D. Kritchevski, J.A Scimeca, P.J. Huth, Dietary conjugated linoleic acid reduces plasma lipoproteins and early aortic atherogenesis in hypercholesterolemic hamsters, Artery 22 (1997) $266-277$.

[14]. L. Cossignani, L. Giua, E. Urbani, M.S. Simonetti, F. Blasi F, Fatty acid composition and CLA content in goat milk and cheese samples from Umbrian market, European Food Research and Technology 239 (2014) 905-911.

[15]. R. Tudisco, M. Grossi, L. Addi, N. Musco, Fatty acid profile and CLA content of goat milk: influence of feeding system, Journal of Food Research 3 (2014) 93-100.

[16]. E. Tsiplakou, K.C. Mountzouris, G. Zervas, Concentration of conjugated linoleic acid in grazing sheep and goat milk fat, Livestock Science 103 (2006) $74-84$.

[17]. A. Nudda, G. Battacone, M.G. Usai, S. Fancelli, G. Pulina, Supplementation with extruded linseed cake affects concentrations of conjugated linoleic acid and vaccenic acid in goat milk, Journal of Dairy Science 89 (2006) 277-282.

[18]. A.P. Simopoulos, The importance of the ratio of omega 6/omega 3 essential fatty acids. Biomedicine \& Pharmacotherapy 56 (2002) 36579.

[19]. M. Kouba, J. Mourot, A review of nutritional effects on fat composition of animal products with special emphasis on $\mathrm{n}-3$ polyunsaturated fatty acids, Biochimie 93 (2011) 13-17.

[20]. A.M. Galina, J. Pineda, R.I.H. Piedrahita, P. Vázquez, G. Haenlein, J. Olmos, Effect of Grazing on the Fatty Acid Composition of Goat's Milk or Cheese, Advances in Dairy Research 7 (2019) 227 DOI: 10.35248/2329-888X.19.7.227

[21]. A.H. Anghel, D. Nadolu, E. Ilisiu, A. Cismileanu, Differences on biochemical composition of goat milk at Carpathian breed and half-breed Saanen X Carpathian and French Alpine X Carpathian, Revista de Chimie 71 (2020) 352-357.

Received: 16.04.2021

Received in revised form: 07.06.2021

Accepted: 09.06.2021 